\title{
Exploration on the university curriculum ideological and political innovation system according to the principles of sustainable development
}

\author{
Xiaoling $\mathrm{Yu}^{*}$ \\ South China Business College Guangdong University of Foreign Studies, Guangzhou, China
}

\begin{abstract}
Quality education is one of the pillars of UN sustainable development. The proposition was pointed out by General Secretary Xi Jinping at the National Conference on the University Ideological and Political Work that "Universities and colleges should be based on the moral and talent cultivation". It was required to take the idea of "Moral and Talent Cultivation" as the university guiding idea and coordinate the development of all kinds of university work, starting from the university ideological and political work. Therefore, under the guidance of the idea of "Moral and Talent Cultivation", this paper is aimed to construct a collaborative innovation system of the university ideological and political education with the whole curriculum, the whole process and the whole-staff cooperation so as to realize the comprehensive education.
\end{abstract}

\section{Introduction}

The system is a whole composed of several things related to and restrict each other. The curriculum system is the overall arrangement, combination and optimization of all kinds of university curriculums. In terms of curriculums, it refers to all the curriculum elements around professional training objectives as well as their arrangement and combination according to different effects and functions. The requirements of the state and the society for talent cultivation are the origin of system construction in the system construction elements of collaborative innovation of university ideological and political curriculums. It should be always grasped and run through the whole process. According to system construction, the mechanism of cultivating university teachers' awareness and ability of collaborative education, the implementation and management mechanism of ideological and political collaborative innovation teaching [1], the platform mechanism of university curriculum ideological and political collaborative innovation and the guarantee mechanism of university curriculum ideological and political collaborative innovation are constructed to further ensure the smooth operation of the university curriculum ideological and political collaborative innovation system.

\footnotetext{
* Corresponding author: 893491023@qq.com
} 


\section{Construction on the whole-curriculum collaborative education system}

In university education, curriculums are the foundation of collaborative innovation of ideological and political education as well as the carrier of ideological and political education elements. Curriculum goals are the premise and foundation of curriculum implementation as well as the expected effect of curriculum development. It is clear that curriculum goals are the primary link of curriculum design. It is of great significance to classify curriculum goals accurately.

Three-dimensional goal penetration of knowledge, ability and value.

For the construction on the university curriculum ideological and political coordination system, it is necessary for us to establish the idea of university curriculums being also inseparable from education goals clearly, set up the three-dimensional goals of knowledge transfer, ability cultivation and value guidance and achieve the unity of three-dimensional goals through teaching design and teaching methods. The three dimensional goals which are inseparable from each other are regarded as the three aspects of curriculum goals. Knowledge transfer, ability cultivation and value guidance are taken as the basic goal, the development goal and the ultimate goal respectively. The university talent cultivation must be based on knowledge transfer and the good knowledge reserve is a pass for college students to enter the relevant industry in the future. It should be based on ability training [2]. Ability and skills are the basic guarantee for college students to enter the society for conscious socialization as well as the core competitiveness of talents in the related industry. It should be centered on value guidance. Value guidance determines the essential question about the object served by the talents from colleges and universities.

Three-level collaboration among subjects, majors and curriculums.

Curriculums are specific teaching subjects as well as the basic elements of majors. Each curriculum is guided by the three-dimensional goals of knowledge transfer, ability cultivation and value guidance to educate people. However, no curriculum is isolated. In terms of position, proportion and goal in the related major, curriculums are endowed with their own advantages. They support the major together and achieve the goal of professional cultivation. Each major is set up according to subjects as well as the market demand. It is endowed with its own logical starting point, cross and correspondency. Therefore, the whole curriculum education of ideological and political collaborative innovation in colleges and universities should be in line with the three-level coordination among subjects, majors and curriculums. Each curriculum of each major under a subject is a whole so as to achieve the education effect of $1+1>2$ in the perspective of system theory.

In the process of the design and implementation of the three-dimensional goals for each curriculum, we should not adopt the "one-size-fits-all" way or confuse professional curriculums with ideological and political theory curriculums but maintain the original academic attributes of professional curriculums, deal with the relationship among correct political direction, value orientation and academic orientation in curriculum teaching, and avoid the "pan ideological and political" tendency of professional curriculums. In particular, for some professional curriculums with strong ideological attributes, it is necessary to carry out curriculum design more carefully and pay more attention to the feelings and acceptance of students.

Collaboration between the ideological and political theory curriculum, the comprehensive quality curriculum (general education curriculum) and the professional curriculum.

Education should return to the main teaching channel, instead of being limited to the ideological and political theory curriculum. Therefore, the content system of the ideological and political collaborative innovation of interdisciplinary curriculums mainly refers to all curriculums including the ideological and political theory curriculum, the professional 
curriculum and the comprehensive quality curriculum (general education curriculum). It is aimed to educate people. The construction on the ideological and political system in colleges and universities should be focused on content to carry out reform and innovation on the ideological and political theory curriculum, the comprehensive quality curriculum (general education curriculum) and the professional curriculum at different levels first.

In terms of the improvement on the ideological and political system of curriculums, we should attach importance to the professional curriculum. Try out the curriculum ideological and political education for the philosophy and social science major with a lot of educational resource on the basis of the special field of vision, theory and method of subjects. Refine the cultural gene and value paradigm contained in the professional curriculum. Search for some referable experience. Realize the organic unity between knowledge teaching and value guidance in professional teaching. Construct the comprehensive three-dimensional framework of the curriculum ideological and political education from the simple labeling and simple methodology to the relatively mature curriculum ideological and political design and from the single curriculum education to the formation of multiple professional curriculum groups to form a complete collaborative education system of the ideological and political education department in combination with the ideological and political education theory curriculum and the comprehensive literacy curriculum (general education curriculum) so as to play a comprehensive ideological and political role.

\section{Construction on the whole-process collaborative education system}

In the traditional sense, curriculum teaching generally refers to the teaching of the first classroom, but in fact, it is far from the completion of education tasks and links. The theoretical knowledge learned by students in class shouldn't be only at the theoretical level, but it is also necessary to realize the value of knowledge in practice and application, which is also the requirement of the whole-process education in the content system of ideological and political cooperation in colleges and universities. Teaching is the first classroom, practice is the second classroom and Internet is the third classroom [3]. The construction on the whole-process education system must cover the three positions of students' education and it is necessary to realize the mutual support among the three classrooms

The goal of the first classroom should be integrated into the second and third classrooms under the guidance of the ideological and political goal of the first classroom to achieve the integrated design among the three classrooms. The methods of the three classrooms to carry out ideological and political education are endowed with their own characteristics and strengths. It is necessary to better consolidate all the results of classroom education in combination of the strengths of the three classroom political education methods. The first, second and third classrooms are dominated by the theoretical education method, the practical education method and the dredging education method as well as the typical incentive method according to the education content respectively. The methods of persuasion education, typical education, incentive education and infection education are interpenetrated in the three classrooms, especially in the third classroom. It is difficult to attract attention through theoretical indoctrination on the Internet and there is no platform for education, resulting in the only possibility to attract and retain students emotionally. Of course, the specific operation and skills of the three kinds of classroom ideological and political education methods is on a trend of ever-changing under different conditions and scope. As a result, it is necessary for teachers to deal with a problem case by case, investigate and grasp it carefully and apply it boldly. 


\section{Construction on the whole-staff cooperation education system}

It is the duty of every teacher to educate students. "It is necessary for every teacher to fulfill responsibility carefully", which is a clear request made by General Secretary Xi Jinping to every teacher. Teachers are the backbone of teaching as well as the subject of curriculums. They play an important role in knowledge transfer, ability cultivation and value guidance. Their educational consciousness and ability play a great initiative role in the implementation of collaborative education of ideological and political education, which determines whether the ideological and political objects of curriculums can be implemented or not. It is the key to getting through the whole curriculum and process of ideological and political education [4].

"If you are close to your teacher, you should believe in his method. If you respect your teacher, you should obey his teaching". First of all, it is necessary for college teachers to make clear and believe in their own methods and set examples for students. In the ideological and political curriculum, teachers of every curriculum are required to combine their majors as well as their curriculum content and characteristics, educate students by making use of Marxist standpoint, views and methods, adhere to the combination of theory and practice and help students solve practical problems such as ideological and psychological life. They should also influence students and guide them to become talents with profound academic quality, excellent ideological, moral character and good moral sentiment.

In order to realize the comprehensive implementation of curriculum ideological and political education, it is essential to cultivate teachers' moral education consciousness and ability. It is necessary to strengthen the related investigation and training. Actively mobilize the education consciousness of all teachers, improve their ability of education and realize their collaborative efforts in education. Just as the labor motto in Chinese folk songs is the password to make workers work together. When the password appears, workers work together. In addition, the password makes workers encourage each other and stimulate their labor enthusiasm.

\section{Conclusion}

In the whole-staff education system of curriculum ideological and political collaborative innovation, all departments and teachers are required to break the original barriers to form a situation of joint education and achieve collaborative interconnection, interoperability and collaborative interaction. Collaborative interconnection to guide students' ideas is just to adopt multiple ways (such as face-to-face and Internet) to communicate with students, understand their ideological trends, solve their ideological and practical confusion and carry out the guiding work better. Teachers should also strengthen communicate with each other, exchange the ideological information of their own students and master the more detailed information, so that they can carry out work better and more targetedly. Interoperability to guide students' study means that teachers should communicate with each other, care about their study, help them improve their learning methods, actively guide them to carry out social practice and scientific research activities and promote their self-development and growth. Collaborative interaction to guide students' life refers to continuously strengthening the interaction between teachers and students through a series of activities, set examples in the process of interaction, guide college students' life better and help them make plans so as to become their intimate friends and life mentors. 


\section{References}

1. S. Bhat, R. Raju, S. Bhat, R. D'Souza, R. Paper presented at the Procedia Computer Science, 172, 906 (2020)

2. T. Budiharso, B. Tarman, Journal of Ethnic and Cultural Studies, 7(1), 99 (2020)

3. E. de Matos Pedro, J. Leitão, H. Alves, Sustainability, 12(2) (2020)

4. C. Doruk, N. Enver, B. Çaytemel, E. Azezli, B. Başaran, Journal of Voice, 34(2), 302.e15 (2020)

5. M.R. Farzanegan, M. Thum, Empirical Economics, 58(4), 1863 (2020)

6. K.N. Kunze, L.M. Krivicich, N.N. Verma, J. Chahla, Journal of Arthroscopic and Related Surgery, 36(1), 233 (2020)

7. E. Kurilovas, Computers in Human Behavior, 107 (2020)

8. F. Marimon, M. Mas-Machuca, J. Berbegal-Mirabent, Total Quality Management and Business Excellence, 31(5-6), 483 (2020)

9. D.M. Nazarov, A.D. Nazarov, D.B. Kovtun, D. B. 2020 IEEE 22nd Conference on Business Informatics, CBI 2020, 2, 106 (2020)

10. M.D.C. Olmos-Gómez, M.L. Suárez, C. Ferrara, E.M. Olmedo-Moreno, Sustainability 12(6) (2020)

11. G. Santos, C.S. Marques, E. Justino, L. Mendes, Journal of Cleaner Production, $256(2020)$

12. M. Sciarelli, M.H. Gheith, M. Tani, TQM Journal, 32(6), 1349 (2020)

13. H. Tilga, V. Hein, A. Koka, M.S. Hagger, Scandinavian Journal of Educational Research, 64(5), 661 (2020)

14. A. Visvizi, L. Daniela, C. Chen, Computers in Human Behavior, 107 (2020)

15. B.N. Wong, K.D. Baum, L.A. Headrick, E.S. Holmboe, F. Moss, G. Ogrinc, J.R. Frank, Academic Medicine : Journal of the Association of American Medical Colleges, 95(1), 59 (2020)

16. M.W. Zafar, M. Shahbaz, A. Sinha, T. Sengupta, Q. Qin, Journal of Cleaner Production, 268 (2020)

17. S. Shi, Ideological \& Theoretical Education, 7 (2017)

18. X. Gao, Open Journal of Social Sciences 8, 8 (2020)

19. The Party Building and Ideological Education in Schools, 12 (2017)

20. L. Ma, X. Gu, W. Li, Heilongjiang Researches on Higher Education, 1 (2019)

21. M. Wang,J. Tao, Theoretical and Practical Research on the Construction on the School Curriculum System (China Social Sciences Press, 2017)

22. R. Zhanbayev, S. Sagintayeva, A. Ainur, A. Nazarov, Mathematics, 8(11), 1 (2020) 